\title{
SOIL POLLUTION LEVEL OF ECOLOGICALLY VULNERABLE AREAS AROUND KAJARAN TOWN AND WAYS OF THEIR IMPROVEMENT
}

\author{
Karen Ghazaryan*, Hasmik Movsesyan, Naira Ghazaryan, Gor Gevorgyan, Karlen Grigoryan \\ Department of Ecology and Nature Protection, Faculty of Biology, Yerevan State University, \\ 1, Alex Manoogian str., Yerevan 0025, Republic of Armenia \\ "e-mail: ghazaryank@mail.ru; phone: + (37491) 342919
}

\begin{abstract}
Kajaran town is situated in the south-east of the Republic of Armenia in Syunik Marz. Developed mining and smelting industries can be observed in this area. This economic sphere is one of the main sources of soil pollution with heavy metals causing desertification of soils. Taking into consideration the location of the main sources of pollution six the most risky sites in this area and an unpolluted site as a control were selected for the study of pollution by heavy metals. The content of metals was determined by means of ELAN 9000 ICP-MS System. Study results revealed the increase up to 17 times in contents of following metals: $\mathrm{Co}, \mathrm{Ni}, \mathrm{Cu}, \mathrm{Zn}, \mathrm{Cr}, \mathrm{Sr}, \mathrm{Mo}, \mathrm{Cd}, \mathrm{Pb}, \mathrm{As}$. Based on Geoaccumulation index $\left(\mathrm{I}_{\text {geo }}\right)$ classification, the soils from all sites may be classified between "practically uncontaminated" and "uncontaminated to moderate". The pollution level for $\mathrm{Cu}\left(\mathrm{I}_{\text {geo }}=0.031-2.468\right)$ was higher than for other metals. The sites adjacent to Kajaran ore-dressing and processing enterprise are classified as "moderately to strongly" contaminated by $\mathrm{Cu}$. Experiments have led us to the assumption that pollution of soils with heavy metals in the studied territory is conditioned by human activities, particularly by mining and smelting industry.
\end{abstract}

Keywords: mining, heavy metals, soil pollution, soil improvement.

\section{Introduction}

The prime emphasis among environmental advocates has always been the protection of human health, with the implicit recognition that human well-being is inextricably intertwined with the health and stability of natural ecosystems of which we form an integral part. Some of today's most prevalent ills are increasingly blamed on toxic environmental contaminants - heavy metals that become pollutants as a result of previous industrial, mining or other activities [12]. Contamination of soils by heavy metals is a significant problem, which leads to negative influence on soil characteristics and limitation of productive and environmental functions $[2,6,7,9,10,11,13-16]$. The accumulation of these contaminants in the environment has become a concern due to the health risks to humans and animals $[4,8,17]$.

Mining industry is a developed branch of the Armenian economy. Since the last decades of the 20th century, mining and beneficiation of a variety of minerals, in particular copper and gold, have been the driving force behind economic development, particularly in RA Marzes (administrative districts) of Syunik and Lori.

The aim of our studies was the evaluation of soil pollution level (particularly by heavy metals) of ecologically vulnerable mining territories around Kajaran town in the RA Marz of Syunik and suggestion of ways for their improvement. The problem under study in this region is very urgent and actual because it concerns the preservation of sensitive natural resources, prevention of inadmissible contamination of food products and the protection of the health of inhabitants in this region. Appropriate management of surroundings of open mines, active tailing dams, sites adjacent to ore-dressing and processing enterprises as well as suggestion of ways for preventing pollution in the surrounding territories are very important. Preventing heavy metal pollution is critical because the cleaning of contaminated soils is extremely expensive and difficult.

\section{Materials and methods}

The lands of the area belong to the type of mountain cambisol. In Armenia this soil type is distributed 500-1700 meters above sea level, and on arid southern slopes it reaches up to 2400 meters [1,3]. The objective of this research was the analysis of soils of six the most risky sites of this region (Figure 1).

It should be noted that the tailing dam of Artsvanik is rather far from Kajaran town nevertheless this site was also chosen as far as it is now the only active tailing dam of the enterprise.

Taking into account the above-mentioned, 18 sections of only horizon A of soil $(0-20 \mathrm{~cm})$ were performed in selected sites. The control section on distance $4 \mathrm{~km}$ from enterprise in a western ward direction was also done (approximately on distance $1 \mathrm{~km}$ westward from Kajaran village). Sections were performed manually. The sampling of soils was carried out in a traditional way, well-known in soil science. All labware and sampling apparatus were pre-soaked in 5\% nitric acid solution followed by distilled water for a day prior to sampling for removing trace concentrations of metals.

Samples of soils were taken from a depth of $0-20 \mathrm{~cm}$ at $5 \mathrm{~m}$ intervals on a grid measuring $20 \mathrm{~m} \times 20 \mathrm{~m}$ and with the center point of the grid at the sample location. After homogenization and removal of unwanted content (stones, plant material etc.) samples were air-dried at room temperature, ground, sieved to pass a $1 \mathrm{~mm}$ mesh and stored in an all-glass jar for analysis of their properties.

The content of heavy metals was determined by means of ELAN 9000 ICP Mass Spectrometer (Perkin Elmer, Inc). 


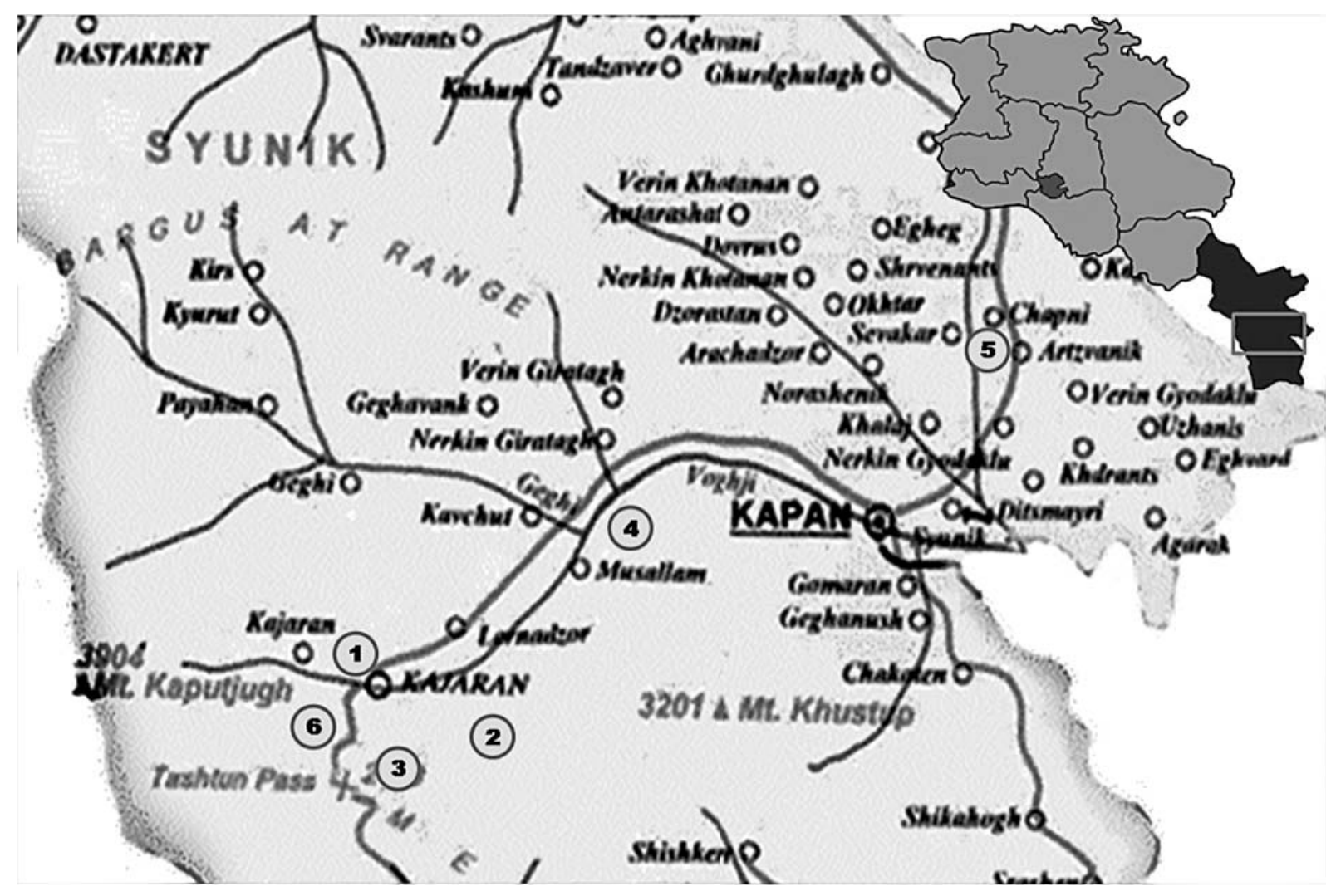

Figure 1. The map of Syunik Marz of Armenia showing six sampling areas:

1. the sites adjacent to Kajaran ore-dressing and processing enterprise (samples no. 1-6),

2. recultivated tailing dam of Pkhrut (sample no. 7),

3. recultivated tailing dam of Darazam (sample no. 8),

4. recultivated tailing dam of Voghii (sample no. 9),

5. surroundings of Artsvanik active tailing dam (samples no. 10-12),

6. surroundings of open mine near the Kajaran town (samples no. 13-18).

To quantify the degree of pollution of soils with heavy metals the Geoaccumulation index, $I_{\text {geo }}$, was used [5]:

$I_{\text {geo }}=\ln \left(C_{n} / 1.5 \times B_{n}\right)$,

where:

$C_{n}$ - measured concentration of heavy metals in the soils from risky sites $(\mu \mathrm{g} / \mathrm{g})$;

$\mathrm{B}_{\mathrm{n}}-$ background value of heavy metals in the soil from control section $(\mu \mathrm{g} / \mathrm{g})$;

1.5 - background matrix correction factor.

The coordinates of sampling sites having been recorded with GPS receiver as well as their pollution with heavy metals have been described in registration book for general evaluation of soil pollution level.

\section{Results and discussion}

The data of field studies indicate that the 19 sections of soil can be classified into types and subtypes. The main soil type in studying sites was the mountain cambisol with its subtypes:

1. a) mountain cambisol, decalcified, rubble-stony, with weak capacity, weakly eroded in some places (samples no. $1-3,13,17$ and the control);

b) mountain cambisol, decalcified, with medium capacity, weakly eroded (samples no. 4-6, 8, 14-16, 18);

2. mountain cambisol, calcareous, steppificated (samples no. 7, 9, 10-12).

The content $(\mu \mathrm{g} / \mathrm{g})$ of some heavy metals in the studied samples of soil is presented in Table 1 . Since the contents of metals and non-metals in soils are specific and depend on the compound of rocks producing the soil and the conditions of soil formation, for determination of pollution level the obtained results were compared with control sample which was considered as a background. Our study revealed the appreciable increase (1.5 to 17 times) in contents 
of following heavy metals: Co (samples no. 4, 7-9, 10, 16, 17), Ni (samples no. 7-11), Cu (samples no. 1-8, 14-18), Zn (samples no. 6-9, 14, 16), Cr (samples no. 7, 9-11, 15, 18), Sr (samples no. 4, 6-8, 13, 14, 16), Mo (samples no. 3-6, 18), $\mathrm{Cd}$ (samples no. 4, 5, 14, 18), $\mathrm{Pb}$ (samples no. 1, 7, 14), As (samples no. 5, 7, 9, 10). Compared to the control sample the significant increase (approximately 17 times) in the content of heavy metals was observed only for copper which was due to the high content of this metal in ores (Table 2). In general the soil samples no.1-6, 8, 14, 16-18 were highly polluted by $\mathrm{Cu}$ and to some extent - by other metals, while the sample 12 was unpolluted.

Table 1

The content $(\mu \mathrm{g} / \mathrm{g})$ of some heavy metals in the studied samples of soil.

\begin{tabular}{|c|c|c|c|c|c|c|c|c|c|c|}
\hline $\begin{array}{c}\text { Sample } \\
\text { number }\end{array}$ & $\mathrm{Co}$ & $\mathrm{Ni}$ & $\mathrm{Cu}$ & $\mathrm{Zn}$ & $\mathrm{Sr}$ & $\mathrm{Mo}$ & $\mathrm{Cd}$ & $\mathrm{Pb}$ & $\mathrm{Cr}$ & $\mathrm{As}$ \\
\hline 1 & 1.607 & 1.092 & 36.082 & 7.196 & 29.444 & 3.822 & 0.032 & 7.002 & 2.558 & 0.224 \\
\hline 2 & 1.634 & 1.535 & 44.840 & 5.943 & 30.939 & 6.937 & 0.025 & 2.359 & 2.621 & $* *$ \\
\hline 3 & 1.162 & 1.145 & 37.498 & 4.547 & 23.005 & 18.436 & 0.042 & 1.834 & 1.955 & $* *$ \\
\hline 4 & 2.130 & 2.226 & 44.980 & 8.285 & 53.383 & 14.745 & 0.045 & 3.144 & 3.583 & 0.199 \\
\hline 5 & 1.512 & 1.586 & 131.573 & 5.047 & 14.741 & 24.848 & 0.052 & 1.242 & 2.105 & 0.941 \\
\hline 6 & 1.526 & 1.860 & 104.975 & 11.255 & 44.037 & 11.850 & 0.034 & 3.264 & 2.579 & 0.802 \\
\hline 7 & 2.456 & 4.784 & 11.500 & 8.877 & 43.028 & 0.291 & 0.028 & 6.358 & 6.985 & 1.234 \\
\hline 8 & 2.030 & 4.071 & 17.853 & 9.880 & 45.541 & 2.389 & 0.031 & 3.565 & 5.276 & 0.730 \\
\hline 9 & 2.367 & 6.150 & 7.287 & 8.460 & 29.518 & 0.698 & 0.035 & 2.861 & 9.116 & 2.148 \\
\hline 10 & 2.090 & 6.697 & 3.526 & 7.039 & 27.820 & $* *$ & 0.027 & 1.551 & 12.619 & 1.170 \\
\hline 11 & 1.553 & 5.106 & 3.421 & 6.630 & 14.080 & $* *$ & 0.032 & 1.770 & 7.791 & 0.578 \\
\hline 12 & 1.611 & 2.824 & 3.074 & 6.497 & 22.135 & $* *$ & 0.020 & 1.091 & 3.994 & $* *$ \\
\hline 13 & 1.348 & 2.892 & 8.737 & 5.285 & 47.217 & 1.403 & 0.024 & 2.156 & 4.466 & 0.705 \\
\hline 14 & 1.458 & 1.429 & 41.246 & 8.419 & 47.583 & 4.081 & 0.047 & 4.994 & 1.572 & $* *$ \\
\hline 15 & 1.326 & 3.370 & 11.879 & 5.473 & 24.932 & 0.935 & 0.027 & 2.217 & 6.749 & $* *$ \\
\hline 16 & 2.309 & 1.772 & 20.978 & 8.661 & 50.155 & 0.736 & 0.018 & 2.126 & 2.515 & 0.452 \\
\hline 17 & 1.995 & 1.846 & 49.894 & 7.836 & 23.607 & 2.271 & 0.017 & 1.024 & 2.772 & 0.862 \\
\hline 18 & 1.387 & 3.794 & 48.187 & 7.191 & 19.062 & 29.699 & 0.076 & 2.739 & 6.317 & 0.837 \\
\hline Control & 1.179 & 2.521 & 7.431 & 5.791 & 25.508 & 6.733 & 0.030 & 2.535 & 3.839 & 0.598 \\
\hline$* *-$ Trace quantities & & & & & & & & & \\
\hline
\end{tabular}

Table 2

Degree of content exceeding of heavy metals (experimental variant/control).

\begin{tabular}{|c|c|c|c|c|c|c|c|c|c|c|}
\hline $\begin{array}{c}\text { Sample } \\
\text { number }\end{array}$ & $\mathrm{Co}$ & $\mathrm{Ni}$ & $\mathrm{Cu}$ & $\mathrm{Zn}$ & $\mathrm{Sr}$ & $\mathrm{Mo}$ & $\mathrm{Cd}$ & $\mathrm{Pb}$ & $\mathrm{Cr}$ & $\mathrm{As}$ \\
\hline 1 & 1.4 & 0.4 & 4.9 & 1.2 & 1.2 & 0.6 & 1.1 & 2.8 & 0.7 & 0.4 \\
\hline 2 & 1.4 & 0.6 & 6.0 & 1.0 & 1.2 & 1.0 & 0.8 & 0.9 & 0.7 & - \\
\hline 3 & 1.0 & 0.5 & 5.0 & 0.8 & 0.9 & 2.7 & 1.4 & 0.7 & 0.5 & - \\
\hline 4 & 1.8 & 0.9 & 6.1 & 1.4 & 2.1 & 2.2 & 1.5 & 1.2 & 0.9 & 0.3 \\
\hline 5 & 1.3 & 0.6 & 17.7 & 0.9 & 0.6 & 3.7 & 1.7 & 0.5 & 0.5 & 1.6 \\
\hline 6 & 1.3 & 0.7 & 14.1 & 1.9 & 1.7 & 1.8 & 1.1 & 1.3 & 0.7 & 1.3 \\
\hline 7 & 2.1 & 1.9 & 1.5 & 1.5 & 1.7 & 0.0 & 0.9 & 2.5 & 1.8 & 2.1 \\
\hline 8 & 1.7 & 1.6 & 2.4 & 1.7 & 1.8 & 0.4 & 1.0 & 1.4 & 1.4 & 1.2 \\
\hline 9 & 2.0 & 2.4 & 1.0 & 1.5 & 1.2 & 0.1 & 1.2 & 1.1 & 2.4 & 3.6 \\
\hline 10 & 1.8 & 2.7 & 0.5 & 1.2 & 1.1 & - & 0.9 & 0.6 & 3.3 & 2.0 \\
\hline 11 & 1.3 & 2.0 & 0.5 & 1.1 & 0.6 & - & 1.1 & 0.7 & 2.0 & 1.0 \\
\hline 12 & 1.4 & 1.1 & 0.4 & 1.1 & 0.9 & - & 0.7 & 0.4 & 1.0 & - \\
\hline 13 & 1.1 & 1.1 & 1.2 & 0.9 & 1.9 & 0.2 & 0.8 & 0.9 & 1.2 & 1.2 \\
\hline 14 & 1.2 & 0.6 & 5.6 & 1.5 & 1.9 & 0.6 & 1.6 & 2.0 & 0.4 & - \\
\hline 15 & 1.1 & 1.3 & 1.6 & 0.9 & 1.0 & 0.1 & 0.9 & 0.9 & 1.8 & - \\
\hline 16 & 2.0 & 0.7 & 2.8 & 1.5 & 2.0 & 0.1 & 0.6 & 0.8 & 0.7 & 0.8 \\
\hline 17 & 1.7 & 0.7 & 6.7 & 1.4 & 0.9 & 0.3 & 0.6 & 0.4 & 0.7 & 1.4 \\
\hline 18 & 1.2 & 1.5 & 6.5 & 1.2 & 0.7 & 4.4 & 2.5 & 1.1 & 1.6 & 1.4 \\
\hline
\end{tabular}


Geoaccumulation index $\left(\mathrm{I}_{\mathrm{geo}}\right)$ and degree of pollution.

\begin{tabular}{|c|c|c|c|c|c|c|c|c|c|c|}
\hline $\begin{array}{l}\text { Sample } \\
\text { number }\end{array}$ & Co & $N i$ & $\mathrm{Cu}$ & $Z n$ & $S r$ & Mo & $C d$ & $P b$ & $\mathrm{Cr}$ & As \\
\hline 1 & $\begin{array}{c}-0.096 \\
/ 0 /\end{array}$ & $\begin{array}{c}-1.242 \\
/ 0 /\end{array}$ & $1.175 / 2 /$ & $\begin{array}{c}-0.188 \\
/ 0 /\end{array}$ & $\begin{array}{c}-0.262 \\
/ 0 /\end{array}$ & $\begin{array}{c}-0.972 \\
/ 0 /\end{array}$ & $\begin{array}{c}-0.341 \\
/ 0 /\end{array}$ & $0.611 / 1 /$ & $\begin{array}{c}-0.811 \\
/ 0 /\end{array}$ & $\begin{array}{c}-1.387 \\
/ 0 /\end{array}$ \\
\hline 2 & $\begin{array}{c}-0.079 \\
10 / \\
\end{array}$ & $\begin{array}{c}-0.902 \\
10 / \\
\end{array}$ & $1.392 / 2 /$ & $\begin{array}{c}-0.380 \\
/ 0 / \\
\end{array}$ & $\begin{array}{c}-0.212 \\
/ 0 / \\
\end{array}$ & $\begin{array}{c}-0.376 \\
10 /\end{array}$ & $\begin{array}{c}-0.588 \\
10 / \\
\end{array}$ & $\begin{array}{c}-0.477 \\
/ 0 /\end{array}$ & $\begin{array}{c}-0.787 \\
/ 0 /\end{array}$ & $-/ 0 /$ \\
\hline 3 & $\begin{array}{c}-0.420 \\
/ 0 /\end{array}$ & $\begin{array}{c}-1.195 \\
/ 0 /\end{array}$ & $1.213 / 2 /$ & $\begin{array}{c}-0.647 \\
/ 0 /\end{array}$ & $\begin{array}{c}-0.509 \\
/ 0 /\end{array}$ & $0.602 / 1 /$ & $\begin{array}{c}-0.069 \\
/ 0 /\end{array}$ & $\begin{array}{c}-0.729 \\
/ 0 /\end{array}$ & $\begin{array}{c}-1.080 \\
/ 0 /\end{array}$ & $-/ 0 /$ \\
\hline 4 & $0.186 / 1 /$ & $\begin{array}{c}-0.530 \\
/ 0 /\end{array}$ & $1.395 / 2 /$ & $\begin{array}{c}-0.047 \\
/ 0 /\end{array}$ & $0.333 / 1 /$ & $0.378 / 1 /$ & $0.000 / 0 /$ & $\begin{array}{c}-0.190 \\
/ 0 /\end{array}$ & $\begin{array}{c}-0.474 \\
/ 0 /\end{array}$ & $\begin{array}{c}-1.506 \\
10 / \\
\end{array}$ \\
\hline 5 & $\begin{array}{c}-0.157 \\
10 / \\
\end{array}$ & $\begin{array}{c}-0.869 \\
10 / \\
\end{array}$ & $2.468 / 3 /$ & $\begin{array}{c}-0.543 \\
/ 0 /\end{array}$ & $\begin{array}{c}-0.954 \\
/ 0 /\end{array}$ & $0.900 / 1 /$ & $0.145 / 1 /$ & $\begin{array}{c}-1.119 \\
/ 0 /\end{array}$ & $\begin{array}{c}-1.006 \\
/ 0 /\end{array}$ & $\begin{array}{c}0.048 \\
/ 1 /\end{array}$ \\
\hline 6 & $\begin{array}{c}-0.147 \\
/ 0 /\end{array}$ & $\begin{array}{c}-0.710 \\
/ 0 /\end{array}$ & $2.243 / 3 /$ & $0.259 / 1 /$ & $0.141 / 1 /$ & $0.160 / 1 /$ & $\begin{array}{c}-0.280 \\
/ 0 /\end{array}$ & $\begin{array}{c}-0.153 \\
/ 0 /\end{array}$ & $\begin{array}{c}-0.803 \\
/ 0 /\end{array}$ & $\begin{array}{c}-0.112 \\
/ 0 /\end{array}$ \\
\hline 7 & $0.328 / 1 /$ & $\begin{array}{c}0.235 \\
/ 1 /\end{array}$ & $0.031 / 1 /$ & $0.022 / 1 /$ & $0.117 / 1 /$ & $\begin{array}{c}-3.547 \\
/ 0 /\end{array}$ & $\begin{array}{c}-0.474 \\
/ 0 /\end{array}$ & $0.514 / 1 /$ & $0.193 / 1 /$ & $\begin{array}{c}0.319 \\
/ 1 /\end{array}$ \\
\hline 8 & $0.138 / 1 /$ & $\begin{array}{c}0.074 \\
/ 1 /\end{array}$ & $0.471 / 1 /$ & $0.129 / 1 /$ & $0.174 / 1 /$ & $\begin{array}{c}-1.442 \\
/ 0 /\end{array}$ & $\begin{array}{c}-0.373 \\
/ 0 /\end{array}$ & $\begin{array}{c}-0.064 \\
/ 0 /\end{array}$ & $\begin{array}{c}-0.088 \\
/ 0 /\end{array}$ & $\begin{array}{c}-0.206 \\
/ 0 /\end{array}$ \\
\hline 9 & $0.291 / 1 /$ & $\begin{array}{c}0.486 \\
/ 1 /\end{array}$ & $-0.425 / 0$ & $\begin{array}{c}-0.026 \\
/ 0 /\end{array}$ & $\begin{array}{c}-0.259 \\
/ 0 /\end{array}$ & $\begin{array}{c}-2.672 \\
/ 0 /\end{array}$ & $\begin{array}{c}-0.251 \\
/ 0 /\end{array}$ & $\begin{array}{c}-0.284 \\
/ 0 /\end{array}$ & $0.459 / 1 /$ & $\begin{array}{c}0.873 \\
/ 1 /\end{array}$ \\
\hline 10 & $0.167 / 1 /$ & $\begin{array}{c}0.572 \\
/ 1 /\end{array}$ & $\begin{array}{c}-1.151 \\
/ 0 /\end{array}$ & $\begin{array}{c}-0.210 \\
/ 0 /\end{array}$ & $\begin{array}{c}-0.319 \\
/ 0 /\end{array}$ & $-/ 0 /$ & $\begin{array}{c}-0.511 \\
/ 0 /\end{array}$ & $\begin{array}{c}-0.897 \\
/ 0 /\end{array}$ & $0.785 / 1 /$ & $\begin{array}{c}0.266 \\
/ 1 /\end{array}$ \\
\hline 11 & $\begin{array}{c}-0.130 \\
/ 0 /\end{array}$ & $\begin{array}{c}0.300 \\
/ 1 /\end{array}$ & $\begin{array}{c}-1.181 \\
/ 0 /\end{array}$ & $\begin{array}{c}-0.270 \\
/ 0 /\end{array}$ & $\begin{array}{c}-1.000 \\
/ 0 /\end{array}$ & $-/ 0 /$ & $\begin{array}{c}-0.341 \\
/ 0 /\end{array}$ & $\begin{array}{c}-0.765 \\
/ 0 /\end{array}$ & $0.302 / 1 /$ & $\begin{array}{c}-0.439 \\
/ 0 /\end{array}$ \\
\hline 12 & $\begin{array}{c}-0.093 \\
10 / \\
\end{array}$ & $\begin{array}{c}-0.292 \\
/ 0 / \\
\end{array}$ & $\begin{array}{c}-1.288 \\
/ 0 /\end{array}$ & $\begin{array}{c}-0.290 \\
/ 0 /\end{array}$ & $\begin{array}{c}-0.547 \\
/ 0 /\end{array}$ & $-/ 0 /$ & $\begin{array}{c}-0.811 \\
/ 0 /\end{array}$ & $\begin{array}{c}-1.249 \\
/ 0 /\end{array}$ & $\begin{array}{c}-0.366 \\
/ 0 /\end{array}$ & $-/ 0 /$ \\
\hline 13 & $\begin{array}{c}-0.272 \\
/ 0 /\end{array}$ & $\begin{array}{c}-0.268 \\
/ 0 /\end{array}$ & $\begin{array}{c}-0.244 \\
/ 0 /\end{array}$ & $\begin{array}{c}-0.497 \\
/ 0 /\end{array}$ & $0.210 / 1 /$ & $\begin{array}{c}-1.974 \\
/ 0 /\end{array}$ & $\begin{array}{c}-0.629 \\
/ 0 /\end{array}$ & $\begin{array}{c}-0.567 \\
/ 0 /\end{array}$ & $\begin{array}{c}-0.254 \\
/ 0 /\end{array}$ & $\begin{array}{c}-0.241 \\
/ 0 /\end{array}$ \\
\hline 14 & $\begin{array}{c}-0.193 \\
/ 0 /\end{array}$ & $\begin{array}{c}-0.973 \\
/ 0 /\end{array}$ & $1.308 / 2 /$ & $\begin{array}{c}-0.031 \\
/ 0 /\end{array}$ & $0.218 / 1 /$ & $\begin{array}{c}-0.906 \\
/ 0 /\end{array}$ & $0.043 / 1 /$ & $0.273 / 1 /$ & $\begin{array}{c}-1.298 \\
/ 0 /\end{array}$ & $-/ 0 /$ \\
\hline 15 & $\begin{array}{c}-0.288 \\
/ 0 /\end{array}$ & $\begin{array}{c}-0.115 \\
/ 0 /\end{array}$ & $0.064 / 1 /$ & $\begin{array}{c}-0.462 \\
/ 0 /\end{array}$ & $\begin{array}{c}-0.428 \\
10 /\end{array}$ & $\begin{array}{c}-2.380 \\
/ 0 /\end{array}$ & $\begin{array}{c}-0.511 \\
/ 0 /\end{array}$ & $\begin{array}{c}-0.540 \\
/ 0 /\end{array}$ & $0.159 / 1 /$ & $-/ 0 /$ \\
\hline 16 & $0.267 / 1 /$ & $\begin{array}{c}-0.758 \\
/ 0 / \\
\end{array}$ & $0.632 / 1 /$ & $\begin{array}{c}-0.003 \\
/ 0 /\end{array}$ & $0.271 / 1 /$ & $\begin{array}{c}-2.619 \\
/ 0 /\end{array}$ & $\begin{array}{c}-0.916 \\
/ 0 /\end{array}$ & $\begin{array}{c}-0.581 \\
/ 0 /\end{array}$ & $\begin{array}{c}-0.828 \\
10 /\end{array}$ & $\begin{array}{c}-0.685 \\
10 / \\
\end{array}$ \\
\hline 17 & $0.121 / 1 /$ & $\begin{array}{c}-0.717 \\
/ 0 /\end{array}$ & $1.499 / 2 /$ & $\begin{array}{c}-0.103 \\
/ 0 /\end{array}$ & $\begin{array}{c}-0.483 \\
/ 0 /\end{array}$ & $\begin{array}{c}-1.492 \\
/ 0 /\end{array}$ & $\begin{array}{c}-0.973 \\
/ 0 /\end{array}$ & $\begin{array}{c}-1.312 \\
/ 0 /\end{array}$ & $\begin{array}{c}-0.731 \\
/ 0 /\end{array}$ & $\begin{array}{c}-0.040 \\
/ 0 /\end{array}$ \\
\hline 18 & $\begin{array}{c}-0.243 \\
/ 0 /\end{array}$ & $\begin{array}{c}0.003 \\
/ 1 /\end{array}$ & $1.464 / 2 /$ & $\begin{array}{c}-0.189 \\
/ 0 /\end{array}$ & $\begin{array}{c}-0.697 \\
/ 0 /\end{array}$ & $1.079 / 2 /$ & $0.524 / 1 /$ & $\begin{array}{c}-0.328 \\
/ 0 /\end{array}$ & $0.093 / 1 /$ & $\begin{array}{c}-0.069 \\
/ 0 /\end{array}$ \\
\hline
\end{tabular}

The degree of pollution of soils with metals was assessed (Table 3) using the Geoaccumulation index $\left(I_{g e o}\right)$ classification (Table 4) by Förstner et al. [5].

Based on the classification, the soils from all sites may be classified between "practically uncontaminated" and "uncontaminated to moderate" by heavy metals $\mathrm{Co}, \mathrm{Ni}, \mathrm{Zn}, \mathrm{Sr}, \mathrm{Mo}, \mathrm{Cd}, \mathrm{Pb}, \mathrm{Cr}$ and As except the site 18 where the soil was moderately polluted with Mo. The pollution level for $\mathrm{Cu}\left(I_{g e o}=0.031-2.468\right)$ was higher than for other metals. Soils from different sites were found to be polluted with copper somehow, and may be classified as "practically uncontaminated" (sites 9-13), "uncontaminated to moderate" (sites 7, 8, 15, 16), "moderate" (sites 1-4, 14, 17, 18) and "moderate to strong" (sites 5 and 6 ). 
It should be noted that such kind of pollution of soils with heavy metals in studied territory is directly due to human activities, particularly to mining and smelting industry. The variation of high pollution with $\mathrm{Cu}$ and some heavy metals near the open mine and in territories that are adjacent to enterprise is due to the character of industrial activities, moving direction of airstreams as well as physical-chemical peculiarities of soils. According to classification the soil from site 12 is the least polluted with the metals. The low rate of soil pollution in the surroundings of Artsvanik tailing dam is conditioned by correct exploitation of tailing dam.

As was mentioned above, comparatively high rate of soil pollution was also observed near the no operating recultivated tailing dams of Pkhrut, Darazam and Voghji. Although the content of copper considering as main pollutant was small in these recultivated soils other heavy metals ( $\mathrm{Co}, \mathrm{Ni}, \mathrm{Zn}, \mathrm{Sr}, \mathrm{Pb}, \mathrm{Cr}, \mathrm{As})$ by their content exceeded control samples 1.5 and more times. Thereby the inhabitants of these territories are not recommended to use these territories for agricultural purposes even as pastures and hayfields.

Table 4

Geoaccumulation index classification.

\begin{tabular}{|c|c|c|}
\hline Geoaccumulation index, $I_{\text {geo }}$ & $I_{\text {geo }}$ class & Contamination intensity \\
\hline$>5$ & 6 & very strong \\
\hline$>4-5$ & 5 & strong to very strong \\
\hline$>3-4$ & 4 & strong \\
\hline$>2-3$ & 3 & moderate to strong \\
\hline$>1-2$ & 2 & moderate \\
\hline$>0-1$ & 1 & uncontaminated to moderate \\
\hline$<0$ & 0 & practically uncontaminated \\
\hline
\end{tabular}

\section{Conclusions}

Taking into consideration the above-mentioned it is necessary to implement recultivation activities in the areas around Kajaran town that constitute the main source of pollution by heavy metals. The recultivation works are advisable to implement by the method of hydroseeding which is considered as a subtype of biological recultivation. The main goal of biological recultivation is the recovery of soil formation natural process, the stimulation of soil self-purification properties and biocenosis self-recovery process. Biological recultivation results in the formation of a landscape with satisfactory biodiversity on disturbed and polluted areas.

As the area of our studies is polluted especially with heavy metals it is also desirable to add to seed mixture using in hydroseeding method the seeds of plants which have the ability of removing selectively some heavy metals from the soil (rose $(\mathrm{Cu}, \mathrm{Fe})$, chalk plant $(\mathrm{Cu})$, violet, penny cress $(\mathrm{Zn})$, joint weed $(\mathrm{Zn}, \mathrm{Pb}, \mathrm{Cd})$, mustard $(\mathrm{Pb}, \mathrm{Cr})$, hibiscus (Co), buckwheat (Ni)) making the process of recultivation more effective.

In addition to the above-mentioned approaches it is also suggested using ameliorants, particularly the mixture of organic fertilizers (manure, biohumus) and natural ameliorants (zeolite, dacite tuff) for utilization of heavy metals or at least for reducing their toxic impact on living organisms and the environment on the whole. It is scientifically proved that it is possible to improve the condition of soils polluted by heavy metals and to decrease the content of mobile forms of these elements by the joint use of natural ameliorants and organic fertilizers.

\section{Acknowledgements}

This work was supported by State Committee of Science MES RA, in frames of the research project No. SCS 13-4C202.

\section{References}

1. Baghdasaryan, A.B.; Abrahamyan, G.S.; Aleksandryan, G.A.; Aslanyan, A.A.; Zohrabyan, L.N. Physical Geography of Armenian SSR; National Academy of Armenian SSR: Yerevan, 1971, 471 p. (in Armenian).

2. CEC Commission of the European Communities Communication of 16 April 2002 from the Commission to the Council, the European Parliament, the Economic and Social Committee and the Committee of the Regions: Towards a Thematic Strategy for Soil Protection; Brussels, 2002, 35 p.

3. Edilyan, R.A. Atlas of Soils of the Republic of Armenia. Yerevan, 1990, 70 p. (in Russian).

4. Huber, S.; Prokop, G.; Arrouays, D.; Banko, G.; Bispo, A.; Jones, R.J.A.; Kibblewhite, M.G.; Lexer, W.; Möller, A.; Rickson, R.J.; Shishkov, T.; Stephens, M.; Toth, G.; Van den Akker, J.J.H.; Varallyay, G.; Verheijen, F.G.A.; Jones, A.R. ENVASSO Environmental Assessment of Soil for Monitoring: Volume I Indicators \& Criteria., Eds. EUR 23490 EN/1., Office for the Official Publications of the European Communities: Luxembourg, $2008 ; 339$ p. 
5. Förstner, U.; Ahlf, W.; Calmano, W. Sediment quality objectives and criteria development in Germany. Water Science and Technology, 1993, 28, pp. 307-316.

6. Friedlová, M. The influence of heavy metals on soil biological and chemical properties. Soil and Water Research, 2010, 5(1), pp. 21-27.

7. Ghazaryan, K.; Movsesyan, H.; Ghazaryan, N.; Grigoryan, K. The ecological assessment of soils around Agarak town. Biological Journal of Armenia, 2013, 65(1), pp. 39-43.

8. Maxwell, N.I. Understanding Environmental Health: How We Live in the World; Jones \& Bartlett Learning: Burlington, 2009, 378 p.

9. Mikanová, O. Effects of heavy metals on some soil-biological parameters. Journal of Geochemical Exploration, 2006, 88, pp. 220-223.

10. Ross, S.M., Ed. Toxic Metals in Soil-Plant Systems; John Wiley \& Sons: Chichester, 1994; 469 p.

11. SQ Soil quality - Guidance on the determination of background values (ISO 19258:2005), 2007, $30 \mathrm{p}$.

12. USDA United States Department of Agriculture Heavy Metal Soil Contamination. Natural Resources Conservation Service. Soil Quality Institute. 411 S. Donahue Dr. Auburn. AL 36832 334-844-4741 X-177, Urban Technical Note No.3, 2000; 7 p.

13. Vodyanitskii, Yu.N. Contamination of soils with heavy metals and metalloids and its ecological hazard (analytic review). Eurasian Soil Science, 2013, 46(7), pp. 793-801.

14. Povar, I.; Spinu O. Buffer properties of soil minerals. Part 1. Theoretical aspects. Chemistry Journal of Moldova, 2013, 8(2), pp. 67-72.

15. Leah, T.; Povar, I.; Lupascu, T.; Andries, S.; Filipciuc, V. Studying the research results regarding fertilizers used in the Republic of Moldova. Chemistry Journal of Moldova, 2013, 8(1), pp. 14-22.

16. Leah, T. Ecological peculiarities of copper chemical forms content in the eroded soils. Chemistry Journal of Moldova, 2013, 8(1), pp. 33-36.

17. Walker, C.H.; Sibly, R.M.; Hopkin, S.P.; Peakall, D.B. Principles of Ecotoxicology; CRC Press: New York, 2012, $386 \mathrm{p}$. 